\title{
Two Cases of Variations of Musculocutaneous Nerve Communication with the Median Nerve
}

\author{
Dos Casos de Variaciones de la Comunicación del \\ Nervio Musculocutáneo con el Nervio Mediano
}

Daosheng $\mathrm{Hu}^{1}$; Yong Zheng ${ }^{2,3}$; Shanshan Peng ${ }^{2}$ \& Chengjun $\mathrm{Hu}^{2}$

HU, D.; ZHENG, Y.; PENG, S. \& HU, C. Two cases of variations of musculocutaneous nerve communication with the median nerve. Int. J. Morphol., 39(4):960-962, 2021.

SUMMARY: To know the nerve variations of brachial plexus and its branches is very important in the management of upper limb nerve injuries. Variations of the brachial plexus are not uncommon, but types of variations are diverse. The unusual communication branches between the musculocutaneous nerve $(\mathrm{MCN})$ and the median nerve $(\mathrm{MN})$ in course were found during routine dissection on the two different left arms of formalin fixed male cadavers. Depending on the position related to the coracobrachial muscle (CBM), one MCN pierced the CBM, the other did not in the two cases. The branches of MCN emerged interior to the coracoid process to innervate the CBM. The present case reports of anatomical variations of nerves can help to manage nerve injuries and plan surgical approaches during surgical procedures.

KEY WORDS: Variation; Communication; Musculocutaneous nerve; Median nerve.

\section{INTRODUCTION}

In general, the anterior group muscles of the brachium and the majorities of anterior compartment of antebrachium are innervated by the musculocutaneous $(\mathrm{MCN})$ and median nerve $(\mathrm{MN})$, respectively. The $\mathrm{MCN}$ originates from the lateral cords, it sends branches or secondary branches to the shoulder (Olave et al., 2009) and then perforates the coracobrachial muscle (CBM), lying between the biceps brachii and brachialis muscles to supply these muscles, after supplying all three muscles of the arm anterior compartment, the MCN continues as the lateral cutaneous nerve proximal to the cubital fossa, then supplies the skin of lateral side of forearm. MN arises from the medial and lateral cords and fuses in axillary region. Although the variations of brachial plexus are not uncommon (Taheri \& Afshar, 2015), the communication branches between the MCN and MN are unusual. The sites where the branches originate are different, so the height and the length of the communication branches are not the same.

In this study, two cases of variations appeared communication branches between MCN and MN were observed in two male cadavers. A case was that MCN trunk did not pierce CBM (Troupis et al., 2015; Nasrabadi et al., 2017), another case did. Especially, the first one is a rare and less investigated variation.

\section{CASE REPORT}

The variations, presented in the cases here, were found during routine dissection in the left upper limbs of two male cadavers. The cadavers were preserved by injection of $4 \%$ formaldehyde in the femoral artery and underwent a year-long immersion in a formalin solution. In the presented cases, there were two cases of communication nerves between $\mathrm{MCN}$ and $\mathrm{MN}$. In one instance, MCN did not pierce CBM but instead of passing below the muscle before continuing between the biceps brachii and brachialis muscles (Fig. 1A), the MCN followed laterally. On the left upper limb, the union of the musculocutaneous nerve with the median nerve occurred at approximately the midpoint of the arm. A communication branch between MCN and MN

\footnotetext{
${ }^{1}$ Division of Hepatobiliary and Pancreatic Surgery, Department of General Surgery, The Second Affiliated Hospital of Dalian Medical University, Dalian, Liaoning, 116023,PR.China.

${ }^{2}$ Department of Anatomy and Embryology, Wuhan University School of Medicine, Wuhan, Hubei 430071, P.R. China.

${ }^{3}$ The author contributed equally to the work.
} 
emerged $4.3 \mathrm{~cm}$ inferior to coracoid process, where it originated from $\mathrm{MCN}$, then the communication branch joined the MN $9.2 \mathrm{~cm}$ below the coracoid process, the communication branch was $6.5 \mathrm{~cm}$ in length at the region of arm from $\mathrm{MCN}$ to $\mathrm{MN}$. The anteroposterior and mediolateral diameter were $0.14 \mathrm{~cm}, 0.275 \mathrm{~cm}$ at origin point, respectively. $10.8 \mathrm{~cm}$ interior to the origin of communication branch, the first motor branch of MCN emerged for CBM $13.5 \mathrm{~cm}$ interior to the origin of communication branch, the more branches of MCN emerged to supply biceps brachii and brachial muscle

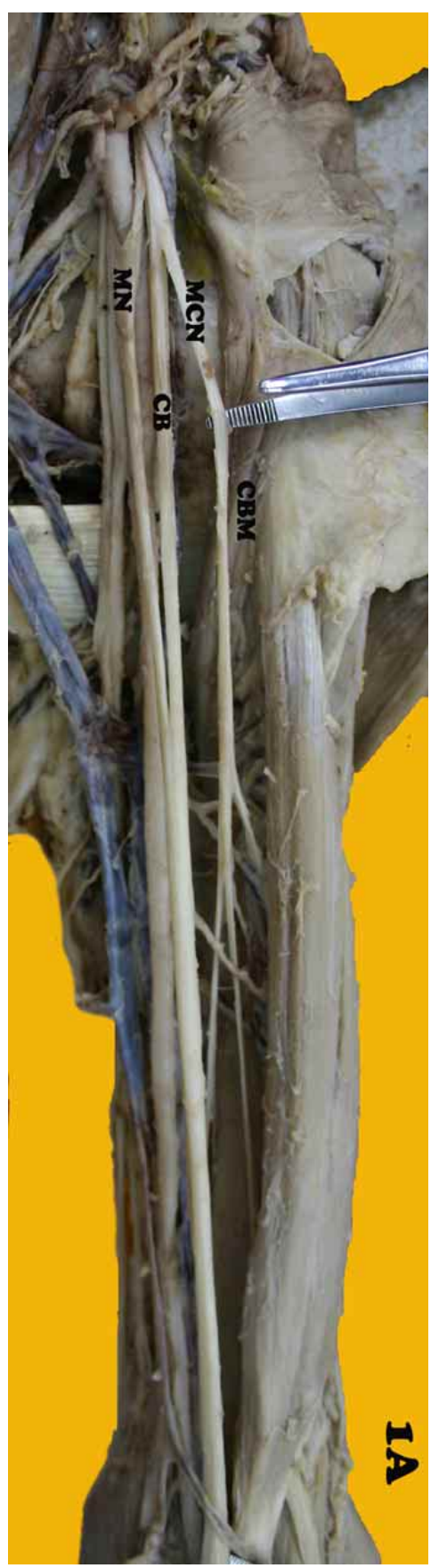

In another instance, in another left upper limb of male cadaver, MCN pierced CBM to supply it (Fig. 1B), the point was $9.8 \mathrm{~cm}$ away from coracoid process, where the MCN entered the CBM. At that level, the communication branch emerged between $\mathrm{MCN}$ and $\mathrm{MN}$, it originated from MCN and joined the $\mathrm{MN}$, which the origin was under the CBM. The communication branch was $8.9 \mathrm{~cm}$ in length at the region on arm, its anteroposterior and mediolateral diameter were $0.10 \mathrm{~cm}, 0.32 \mathrm{~cm}$ at origin point, respectively.

After the anastomotic branch, the MCN descended into motor branches for the anterior group muscles of the brachium. Under the CBM, the MCN passed for $1.5 \mathrm{~cm}$ to this muscle.MCN followed $1.8 \mathrm{~cm}$ and $7.6 \mathrm{~cm}$ up to its second and third motor branches to biceps brachii and brachialis, respectively. After supplying the three muscles of the arm anterior group, $\mathrm{MCN}$ pierced the deep fascia and continued superficially laterally to the biceps brachii muscle tendon as the lateral cutaneous nerve of the forearm.

\section{DISCUSSION}

In order to prevent lesions during surgical procedures, $\mathrm{MCN}$ and $\mathrm{MN}$ have been studied due to the large number of variations encountered in the operation and regional anaesthesia to the upper limb.

In these two cases, there was a communication in course between the two unilaterally in each left upper limb, communications between the MCN and MN in the arm were found unilaterally in $4 \%$ (Kara et al., 2018). For above descriptions, the each communication branch was present in the arm, none of them was seen in the forearm. Depending on the position related to the coracobrachial muscle), one $\mathrm{MCN}$ pierced the CBM, another one did not do in the two cases. MCN not piercing coracobrachialis is a rare and less investigated variation. In this study, a case of coexistence of variations was presented.

Fig. 1. Major components in axilla and arm. A. MCN did not pierce CBM. B. MCN pierced CBM to supply it. MCN: musculocutaneous nerve. MN:median nerve. CBM:coracobrachial muscle. $\mathrm{CB}$ : communication branch. 
In 2017, a novel classification of MCN variations was reported by Mari Hayashi. The classifications of communication branch was five types, our variation was similar with one proposed type described by the author: type I, but the height and the length of the communication branch were not fitted into the described ones.

We know that the main trunk of $\mathrm{MN}$ is formed by some fibers of medial and lateral roots, the remaining root fibers run in the MCN may form the communication branch in the distance to join the main trunk of the MN.

The communication branches are anomalous pattern between the $\mathrm{MCN}$ and $\mathrm{MN}$, which is a congenital variation related to embryogenesis (Namking et al., 2017) and many factors influence the formation of the upper arm's muscles and their nerves. In the two cases, each variation was unilateral and not bilateral, so it was not purely genetic. Iwata (1960) thought that the MCN was derived later from the MN, the failure of nerve fibers differentiation might lead to presence of communicating branch, which leads to such different types of variations in innervation (Radunovic et al., 2013). The communicating branch may represent the primitive nerve supply of the anterior arm muscles and impacts significantly on muscle innervation and consequently on appearance of a variety of neuropathies. So it is easy to explain that the injuries of MCN may lead to weakness of the forearm flexors and thenar muscles.

Such type of neural anomaly might enrich our knowledge, to be aware of the presence of communicating branch from MCN joining MN (Prasada Rao \& Chaudhary, 2000), which is important for clinician or surgeons to perform surgical procedures in the axillary region and in the upper arm (Namking et al.). Its presence must be kept in mind, if it is encountered, the clinicians should modify their therapeutic or surgical intervention to avoid unwanted dysfunction.

The clinician or surgeon should be aware of the presence of communicating branch and its variations in origin, course and relationships in the upper arm (Chrysikos et al., 2020).

HU, D.; ZHENG, Y.; PENG, S. \& HU, C. Dos casos de variaciones de la comunicación del nervio musculocutáneo con el nervio mediano. Int. J. Morphol., 39(4):960-962, 2021.

RESUMEN: Conocer las variaciones nerviosas del plexo braquial y sus ramas es muy importante en el tratamiento de las lesiones nerviosas de los miembros superiores. Las variaciones del plexo braquial no son infrecuentes, sin embargo los tipos de variaciones son diversos. Los ramos inusuales de comunicación entre el nervio musculocutáneo (NMC) y el nervio mediano (NM) en curso fueron descubiertos durante la disección de rutina en dos miembros superiores izquierdos de dos cadáveres de sexo masculino fijados con formalina. Un NMC atravesó el MCB, otro no lo hizo en los dos casos. Los ramos de NMC emergieron a nivel del proceso coracoideo para inervar el MCB. Los presentes informes de casos de variaciones anatómicas de los nervios pueden ayudar a tratar las lesiones nerviosas y planificar los abordajes quirúrgicos durante los procedimientos quirúrgicos.

PALABRAS CLAVE: Variación; Comunicación; Nervio musculocutáneo; Nervio mediano.

\section{REFERENCES}

Chrysikos, D.; Athanasopoulos, A.; Georgakopoulos, P.; Antonopoulos, I.; Samolis, A. \& Troupis, T. Anatomical variation of a communicating branch between the musculocutaneous and the median nerve: a case report. Acta Med. Acad., 49(1):71-4, 2020.

Iwata, H. Studies on the development of brachial plexus in Japanese embryo. Rep. Dept. Anat. Mie. Prefect. Univ. Sch. Med., 13:129-44, 1960.

Kara, A. B.; Elvan, Ö.; Öztürk, N. C. \& Öztürk, A. H. Communications of the median nerve in foetuses. Folia Morphol. (Warsz.), 77(3):441-6, 2018.

Namking, M.; Chaiyamoon, A.; Chaijaroonkhanarak, W.; Khamanarong, K.; Woraputtaporn, W. \& Iamsaard, S. Incidence of unusual formation of the median nerve in thai-northeast embalmed cadavers. Int. J. Morphol., 35(1):52-5, 2017.

Nasrabadi, H. T.; Abedelahi, A.; Shoorei, H.; Shokoohi, M.; Salimnejad, R.; Dolatkhah, M. A. \& Seghinsara, A. M. A variation of Musculocutaneous nerve without piercing the coracobrachialis muscle while communicating to the median nerve: A case report and literature review. Int. J. Surg. Case Rep., 41:453-5, 2017.

Olave, E.; Gabrielli, C. \& Braga, M. T. T. Innervation patterns and biometric localization of the motor points of the brachial biceps muscle in man. Int. J. Morphol., 27(2):495-501, 2009.

Prasada Rao, P. V. \& Chaudhary, S. C. Communication of the musculocutaneous nerve with the median nerve. East Afr. Med. J., 77(9):498-503, 2000.

Radunovic, M.; Vukasanovic-Bozaric, A.; Radojevic, N. \& Vukadinovic, T. A new anatomical variation of the musculocutaneous and the median nerve anastomosis. Folia Morphol. (Warsz.), 72(2):176-9, 2013.

Taheri, M. M. H. \& Afshar, M. Connection between radial and ulnar nerves at humeral level and its clinical significance: a cadaveric case report. Int. J. Morphol., 33(4):1559-62, 2015.

Troupis, Th.; Michalinos, A.; Protogerou, V.; Mazarakis, A. \& Skandalakis, P. Complex anatomic variation in the brachial region. Folia Morphol. (Warsz.), 74(1):118-21, 2015

\author{
Corresponding author: \\ Dr. Chengjun $\mathrm{Hu}$ \\ Department of Anatomy and Embryology \\ Wuhan University School of Medicine \\ 185 Donghu Road \\ Wuhan, Hubei 430071 \\ CHINA
}

E-mail: chengjunhu@whu.edu.cn 